\title{
Decision Premises, Institutions and Organisation
}

\author{
Brian J. Loasby
}

\section{OpenEdition}

Journals

Electronic version

URL: http://journals.openedition.org/ei/711

DOI: 10.4000/ei.711

ISSN: 2553-1891

\section{Publisher}

Association Économie et Institutions

\section{Printed version}

Date of publication: 1 December 2002

Number of pages: 145-166

ISSN: 1775-2329

\section{Electronic reference}

Brian J. Loasby, « Decision Premises, Institutions and Organisation», Économie et institutions [Online], 1 | 2002, Online since 31 January 2013, connection on 03 May 2019. URL : http:// journals.openedition.org/ei/711 ; DOI : 10.4000/ei.711 


\title{
Decision Premises, Institutions and Organisation
}

\author{
Brian J. Loasby \\ Department of Economics, University of Stirling \\ Stirling FK9 4LA \\ Tel +441786467470 \\ Fax +441786467469 \\ e-mail b.j.loasby@stir.ac.uk
}

Herbert Simon (1976, p. xii) proposed that decision premises should be a primary focus of analysis for the study of organisations. This proposal has been ignored by almost all economists, and it has been explicitly rejected by the leading economist of organisation who is familiar with Simon's work. In The Mechanisms of Governance, Oliver Williamson (1996, p. 44) argues that no usable analytical structure for explaining organisational forms has been built on decision premises, in contrast to the manifest successes of transaction cost economics. The evidence, whether interpreted as the revealed preference of economists or as the supposedly decisive evolutionary test of survival, is apparently clear. Nevertheless, I suggest that the issue is still open. Though this paper is primarily concerned with organisational forms and organisational behaviour, I propose to begin, as economists profess to begin and as Simon does, with the individual decision maker; this will enable us to see both why decision premises may be worth specific attention and why economists have very rarely given them that attention.

\section{The Premises of Theory}

In standard economics, behaviour is the direct result of the rational choices of economic agents. That the ability to perform the chosen actions is simply incorporated in the assumptions about human knowledge is a major issue which I have explored elsewhere (Loasby 1998, 1999); our present concern is that the definition of rationality in standard economics makes these choices the logical precipitate of the premises from which the agent starts. Economic theory itself is a logical system, which is ideally derived from a complete and comprehensive axiom set; thus the theorist creates knowledge only in the limited sense of revealing what is already implicit in the starting conditions - and so does the economic agent. The process of deriving necessary implications may be difficult, and sometimes yields results which are surprising; but in principle this process contributes nothing to the outcome, which (in the absence of 
logical error) is predetermined. For both theorist and agent, the premises are decisive: what one can get out depends on what one has put in. Why, then, are these premises not the prime focus of enquiry? The answer is simple: the premises are not believed to be problematic. For the economist, the major premises of good theory are known, and they guide the prescription of the minor premises that are appropriate to particular problems; for the agent the premises are the basic data of the system, including the correct model of that system. 'And so we have man in this situation: what is "the best" for him is known to him uniquely and for certain; how to attain it is dictated by circumstances, and can be inferred from them. ... Conventional economics is not about choice, but about acting according to necessity' (Shackle 1961, p. 272).

In formal organisations, decisions are distributed between agents, but their structure is unchanged. Decision premises are natural givens, and so the 'problem of arranging this complex system into an effective scheme' (Simon 1976, p. xii) is simply a problem of the efficient allocation of decisions, which is a logical operation. Williamson claims that this allocation is explained by transaction cost theory. '[T]he rejection of satisficing in favour of economizing' (Williamson 1996, p. 44) is essential to this explanation, since it prescribes a direct application of the agent's preference function, unqualified by any cognitive limitations. However, Williamson's insistence on economising has the unacknowledged effect of devaluing his acceptance of bounded rationality, to which satisficing is an intelligent response. Simon's (1976, p. xxxvii) argument that decision premises are actually the means of including rationality, interpreted as thoughtful problem-solving, in human behaviour illustrates the extent of the conceptual difference between them.

Williamson's transaction cost theory neatly demonstrates that the premises from which we attempt to construct new theory may be decisive for the development of knowledge. Indeed his explicit rejection of Simon's theoretical premises reveals an implicit belief that premises are chosen and that these choices matter, though apparently not for economic agents. However, the premise that economists should explain the relative domains of firms and markets as an equilibrium allocation is beyond even the thought of questioning; nor is it surprising that the allocation is presented as a farsighted contract, and that the only costs are those attributable to misaligned incentives and asymmetric information, which sometimes frustrate the ideal contracts of a supposedly pure 'market system'. That this is an allocation, not of productive activities but of the interfaces between them, which turns on the relative costs of 
contract and governance across these interfaces, has impoverished the economic theory of both production and organisation.

This is just one example of the ways in which the decision premises of economists have shaped the development of economics. Since no economist has any difficulty in pointing to mistakes in the basis of reasoning by some other economists, one might think that all economists would readily agree that the choice of premises for economic reasoning is an important topic for discussion. That this conclusion is false indicates that there is something wrong with its premises. What is wrong, I believe, is not only that most economists have very little idea how such a discussion could be organised; they assume, and are encouraged by their training to assume, that the basic questions have all been settled. Time is not wasted on methodology (except for training in econometrics); economists get on with their work. One consequence, as Leijonhufvud (1998) has shown, is that economists who are thoroughly trained to use the decision premises of modern theory have no possibility of understanding Keynes' theory of unemployment.

The assumption that all the basic questions of economic theorising have been settled leads naturally to theories which implicitly assume that the basic questions about agents' decision premises have also been settled. Everyone knows how to decide what to do, as well as how to do it; and everyone decides in the same way. Macroeconomic theory therefore needs only a single representative agent (which does not leave much scope for co-ordination failure); in game theory and transaction cost economics it is necessary to have at least two agents, but they are still representative agents who can be transposed without affecting the analysis. As Douglas (1995, p. 102) observes of Williamson's work, 'firms vary, but not individuals'. That, fundamentally, is the reason for the absence of surprise, victims, and the like' (Williamson, 1996, p. 46); it is also the reason why economic theories, including transaction cost theories, so rarely mention entrepreneurship, and why the modelling of innovation in standard economics is so inadequate. On these premises, the firm is necessarily a defence against opportunism; it cannot be a means for the discovery and exploitation of opportunities, for undiscovered, let alone unexploited, opportunities cannot exist in a world of farsighted rationality, where information may be asymmetrical but knowledge is never in doubt. Casson (2000, p. 281) recognises this implication of the standard premises but is unwilling to challenge them, even when claiming to set the agenda for the study of international business. The impression of the development of economics given in the textbooks (when any impression at all is given) is misleading for precisely the same reason. 
One advantage of this commonality of issues is that discussions of decision premises in the economy and in the economics profession can illuminate each other; and though the primary focus of this paper is the former I would like next to consider an earlier example of a choice of decision premises which has had widespread effects, including a major impact on economists' understanding of the rationale of the firm. (For a more extensive treatment see Loasby 2002.) There is abundant textual evidence that Marshall believed the choice of premises for economic analysis to be of prime importance, and was anxious that the wrong choice should not be made; but Adam Smith might have warned him that his own proposal to begin with static equilibrium and then switch to evolutionary models for advanced work created a 'gap'in the chain of connections that was likely to disconcert the imagination of economists too severely to be tolerated (Smith 1980 [1795]).

It was Piero Sraffa who declared this gap to be unacceptable. The first half of his celebrated article on The laws of return under competitive conditions'(Sraffa 1926) was based on a paper published in Italian in the preceding year, now available in an English translation. Sraffa demonstrates in considerable detail the difficulty of reconciling either increasing or decreasing return with perfectly competitive equilibrium, and without further argument declares 'we must then concede that, in general, commodities are produced under conditions of constant costs' (Sraffa 1998 [1925], p. 363). Perfectly competitive equilibrium is treated as a fundamental and undiscussable decision premise, and variable returns can therefore have no place in economic theory. Sraffa's conclusion in 1926 was somewhat different: then it was perfect competition that had to be rejected, but static equilibrium remained untouchable. The attempts by Richard Kahn and Joan Robinson to follow this advice did not meet with Sraffa's approval (Marcuzzo 2001, pp. 87-92), and so in his final contribution to this discussion Sraffa (1930, p. 93), not yet being ready to present his own solution, was content to insist that Marshall's theory should be discarded. Premises have to be chosen to match the competence of the analyst, as Hicks (1939, pp. 83-5) was characteristically open in admitting; theoretical possibilities are constrained by the perceived bounds of rationality.

Let us compare this choice of decision premises with that of Allyn Young in 1928. As Currie (1997) and Ravix (1997) have reminded us, Young extended Smith's theory of economic progress through the division of labour and Marshall's theory of internal and external economies through internal and external organisation into a vision of economy-wide interactive development. 'New products are appearing, firms are assuming new tasks, and new industries are 
coming into being. In short, change ... is qualitative as well as quantitative. No analysis of the forces making for economic equilibrium ... will serve to illumine this field, for movements away from equilibrium, departures from previous trends, are characteristic of it' (Young 1928, p. 528). 'Every important advance in the organisation of production ... alters the conditions of industrial activity and initiates responses elsewhere in the industrial structure which in turn have a further unsettling effect' (Young 1928, p. 533); and the costs of this developmental process are "not the "costs" which figure in an equilibrium of costs and advantages' (Young 1928, p. 535). Some of them are clearly what Langlois (1992) has called 'dynamic transaction costs': the costs of changing both production methods and the organisational arrangements, within and between firms, in order to institute and then improve upon those changes.

Though implicitly agreeing with Sraffa that increasing returns and the equilibrium of the perfectly competitive firm are incompatible, Young made the contrary assumption, that premises should be factually correct rather than theoretically tractable; consequently it was static equilibrium that was unacceptable. Like Sraffa, he did not argue the case; but he clearly believed that there was a choice to be made, and that this choice was of the first importance. Ravix (1997) claims that this was a choice about both economic method and the explanation of economic development, and that Young's emphasis on the growth of productive knowledge matched his conception of the most effective means of progress in economic science. There is, I believe, no simple operational rule by which premises should be chosen, because the consequences of the choice cannot be known in advance; the choice of premises is a scientific art, requiring some kind of tradeoff between tractability and representational sufficiency - precisely what Simon called procedural rationality.

The challenge left by Marshall to his successors as a result of his own particular tradeoff evoked orthogonal responses, with potentially orthogonal consequences. From Sraffa's 1925 paper we can derive the Chicago insistence on using perfect competition and ignoring the plausibility of assumptions, and from his 1926 paper we can derive imperfect competition theory, structure-conductperformance models, the identification of widespread market failure and the hostility to increasing returns so memorably expressed by Samuelson (1972 [1967]). From Young's premises we can derive his own conclusion that the interactive process of increasing return is the source of economic progress, which cannot be adequately considered at the level of the firm alone - as Marshall's treatment had clearly indicated. In this perspective the theory of the firm which 
arose in the 1930s was the logical response to an incorrectlyformulated problem.

Though admiring Walras's achievement, Schumpeter (1934) insisted that the premises of Walrasian general equilibrium were quite inappropriate to a theory of economic development; and Penrose $(1959,1995)$ followed his example in explicitly dissociating her theory of the firm as an agent of development from equilibrium theory. Though she does not refer to Young her theory can be encompassed within Young's premises by setting it in the context of Richardson's (1972) vision of the evolving organisation of industry, which explicitly relies on Penrosian firms. We may also interpret Chamberlin's (1933) theory of monopolistic competition as a dynamic analysis of specialisation, innovation, and market development, presented in a static guise as a result of an inappropriate theoretical premise (Robinson 1970). I will just pose the unanswerable question of how Chamberlin might have developed his ideas had Young, who had been his thesis supervisor, not died and been succeeded by Lionel Robbins, whose own decision premises were quite different.

\section{The Bounds of Rationality}

If the premises from which economists work have significant effects on the development of economics, is it not likely that the premises from which economic agents work will have significant effects on the choices that they make? In order to emphasise the distinctive implications of taking decision premises seriously, I propose to impose three drastic restrictions on my argument - none of which I believe are finally acceptable in a satisfactory analysis of business behaviour.

First, I shall be concerned only with decisions that are taken for what are considered to be good reasons, though certainly not only with decisions that turn out well. This excludes many decisions which need to be understood for any comprehensive explanation of the working of an economy - or the working of the economics profession; but 'rationality' is such a core concept in economics that it is appropriate to focus here on reasoned decisions. Like Williamson, my presumption in what follows is that agents are seeking efficiency; but it is obvious that they do not always achieve it. Like Hayek, I believe that we need to understand success before we can explain failure; but I also believe that in order to include both success and failure within a single analytical scheme we need to model processes which are inherently fallible, and not simply 
because of an unexplained error term or the invocation of 'trembling hands'. I shall argue that it is the need to impose premises that necessarily entails fallibility, even if the subsequent logic is flawless. Second, I shall assume the faultless application of logic (which is rarely observed in practice). Third, although routine behaviour is also governed by decision premises, in the form of a classification system to which phenomena are assigned and a set of actions which is matched to this system, these premises will not be investigated here, in order to concentrate on the premises, rules and routines that frame logical operations.

In the comprehensive general equilibrium model as perfected by Arrow and Debreu allocations are derived directly from the data of the economy; there is strictly no scope for decisions and therefore no scope for decision premises. If agents are to be allowed into such an analytical system, it can only be by providing them with the data relevant to their own situation; thus there is no distinction between decision premises and data, and therefore no distinct analytical category. In the terminology of Potts (2000) the economic system is fully connected, and the choice of connections cannot therefore be a focus of study. Even if some restriction is imposed on the information to which agents have access, this information is derived from a full information set which maps precisely onto the data; the decision premises therefore do not appear to need attention in their own right.

In this perspective it is not surprising that Simon's conception of bounded rationality should be understood as truncated rationality, in which the set of decision premises has to be adjusted to the limited human capacity for logical processing. It is an obvious inference that decisions are to be explained by the way in which the premises are truncated; nevertheless the standard assumption in treatments of information problems in economics that a full information set always exists, but is costly to acquire and may be inaccessible to some agents, allows a formal analysis to be applied to the acquisition of information or to a decision based on asymmetric information when the implications of this asymmetry are known. Thus the reduced set of premises is itself optimised, and any departure from unconstrained optimisation is precisely adjusted to information costs. (Standard transaction cost analysis relies on such a second-level optimisation.) The belief that this is an appropriate response to Simon's insistence that rationality is bounded may be encouraged by Simon's own frequent use of chess as the archetypical example, for the derivation of an optimal strategy for chess is in principle a fully specified problem for someone with sufficient cognitive capacity. Simon's point that even such 'optimisation in 
principle' cannot be translated into any feasible scheme of 'optimisation in practice' is simply ignored.

The conception of truncated rationality as an approximation, good or bad, to a fully-specified problem grossly understates the difficulties that we face through the intersection of complexity, interdependence, and cognitive limitations; 'rational choice', as defined by economists, is impossible, not because of difficulties with formal reasoning but because there can be no way of knowing that the premises for such reasoning are correctly specified. The absence of any procedure that is known to be correct is the distinguishing characteristic of uncertainty, as defined by Frank Knight (1921), and it is this characteristic, Knight argues, which is a necessary condition for profit, entrepreneurship and the firm. I propose to extend his argument by claiming that it is a necessary condition for the emergence of institutions, which help us to cope with situations in which rational choice, strictly defined, is impossible. It follows that institutions themselves cannot be the product of human design, in the sense of rational choice; however this certainly does not exclude elements of design, and especially of intentionality, in the process by which an institution develops. Purpose amidst uncertainty can be an effective driver of evolution.

In conditions of Knightian uncertainty or Simonian bounded rationality our logical processing must be based on a problem formulation which exists in the space of representations; we cannot derive our decision premises from the phenomena but have to impose a set of premises that we believe, or hope, will be adequate. Not only is a fully-connected system unattainable; even the selection of connections is fallible, but some connections must be imposed before we can apply reason. (Even deriving a winning strategy from the rules of chess is a problem of Knightian uncertainty; that is why there can be Grand Masters, whose skills cannot be replicated by any formula.) 'It is clear that to live intelligently in our world ... we must use the principle that things similar in some respects will behave similarly in certain other respects even when they are very different in still other respects' (Knight 1921, p. 206). It is obviously important that the similarities should be important and the differences irrelevant; but whether this is so for any decision must depend, in ways which can never be known for certain, on the particular circumstances of that decision.

We should therefore concentrate on the variety of ways in which problems may be truncated, or framed. 'Framing effects' are sometimes blamed for supposedly 'irrational' decisions; but all reasoned decisions must be set within a pre-analytical framework 
which prescribes the relationships to be investigated and (often unconsciously) the relationships to be ignored, the criteria to be applied, which are typically sub-objectives, and the procedures to be used. Because no framework will be best for all purposes there is always a potential for failure through applications which turn out to be misjudged; the 'logic of appropriateness', when correctly applied, ensures internal but not external coherence. But in addition to examining specific situations, we should recognise that an efficient system response to bounded rationality, and specifically to the insufficiency of any single set of premises, is offered by the division of labour, which leads to the differentiation of knowledge. The division of labour is, in part, a means of economising on rationality through the specialisation of decision premises, which encourages the evolution of premises which appear to be sufficient for particular classes of problem, and thereby increases the effectiveness of human reason.

However as knowledge grows in this way it becomes increasingly dispersed and asymmetric. Not only will different specialists know different things; they will formulate their knowledge in different ways, which may make communication difficult, and even sometimes dangerous because the receiver's interpretation may be inconsistent with the sender's intention. (This possibility is ignored in almost all economic analyses of information: even 'selfdisbelieved promises' are assumed to be interpreted as the deceiver intended.) Information has no significance without context, and the context for interpretation is provided by the premises on which the interpreter relies. As these become increasingly diverse, shared interpretations may become increasingly difficult to achieve especially if people come to believe (as economists, for example, have done) that their particular interpretative premises have nearuniversal validity. Co-ordination may therefore be problematic even in a world of universal benevolence.

The conclusions that we reach by formal reasoning may be in error because the selection of premises is faulty; and this selection must be made by non-logical means. In the most formal of sciences, the identification of ideal with empirical statements is not deductive. Having neglected the uncertainty in our premises, we can never be sure of the logical necessity of our conclusions. Every theoretical calculation becomes metaphorical' (Ziman 1978, p. 27). This is true of economic theory, as of all sciences, and of decisions in business and in our daily lives. The choice of premises for scientific analysis sets limits to our knowledge; but without such constraints no knowledge is possible. Similarly, the choice of decision premises by economic agents sets limits to their actions, but without such limits 
no reasoned action is possible. Moreover, knowledge may be false, and actions may be mistaken. The recognition of these limitations has logical implications for the conduct of scientific research and of economic activities.

We can now identify four themes for analysis and empirical study. The first is the distribution of different clusters of premises within the economy, or the basic pattern of specialisation in decision making. The second is the relationship among those within a particular specialism: how are they grouped and what contacts do they have? The third is the pattern of premises currently favoured in that specialism, and the implications for what those who work within it can and cannot do, and for what they can and cannot perceive. The fourth is the relationship between different categories of specialists, and in particular the arrangements for co-ordinating complementary knowledge, much of which relies on disparate frameworks, both within and between organisations. Here are the basic issues of economic organisation. It is my view that a fundamental premise for analysing them is the context of the growth of knowledge; reasoning in terms of fixed information sets is as likely to lead to misleading conclusions as reasoning in terms of given products and technologies in the 1930s. Opportunism, on the other hand, although significant, does not seem to me fundamental to an explanation of industrial organisation, for reasons to be briefly considered later. It needs to be incorporated at an early stage, but the problems and opportunities of developing and co-ordinating knowledge deserve priority.

\section{Institutions and Organisation}

An exploration of these themes is far too large a task for the remainder of this paper, which will be limited to indicating some of the implications of bounded rationality for organisational design and behaviour and the pervasive importance of institutions. We begin with the problems faced by each individual in trying to behave reasonably: how is a situation to be framed in order that we may select an action; how are we to close our model in order to put logic to work? Our cognitive powers are so limited in relation to the complexity around us that we very often feel in need of some assistance in filling the gaps. If we always had to give conscious thought to our decision premises we would make very few decisions. We therefore often look around for help, hoping to follow the example of someone who may be more skilful in coping with a particular kind of situation. It is in this search for good practice, and the consequent 
adoption of frameworks and procedures which seem to work for others, even when co-ordination is not an issue, that Choi (1993) finds the origins of institutions, which provide us with ready-made decision premises and rules of procedure. Institutions help us to close our decision models and thus permit logical deduction within a plausible framework. Furthermore, shared conventions help us to understand the behaviour of those who share them (Heiner 1983), and create the possibility of tacit co-ordination. What frameworks are plausible may vary between groups and over time; and institutions may accordingly be local or general, and may change.

Any society requires some institutions of very broad scope; more specialised groupings, such as the community of economists, develop more specialised premises which both assist the individual and facilitate co-ordination within particular areas of interest. (For an insider's exploration of the institutions of science see Ziman 2000.) All effective human interaction depends on intersubjectivity for example, the shared attribution of 'moneyness' to certain pieces of paper, the shared interpretation of marks on other pieces of paper as the tracks of subatomic particles, the shared belief that replicator dynamics provides insight into biological processes or the fortunes of a group of firms, the shared response that a report from a firm's research department defines a productive opportunity. The division of cognitive labour focuses the attention of each category of specialist on particular phenomena, on particular ways of classifying them, and on particular ways of formulating problems in order to make them accessible to particular logical techniques and the experimental techniques which are associated with them; and it allows those within each category to learn from each other, even if they are in competition.

A firm is such a specialised grouping, which must draw on the institutions of a wider society in order to get started but then develops particular institutions on which individuals come to rely for simplifying their own decision making and as a basis of co-ordination within the organisation. If we begin, like Coase, with a theory of market co-ordination, but with a more detailed appreciation than Coase had acquired in the early 1930s of the reliance of rigorous theory on prices that are known (without cost) to be equilibrium prices, then we can regard the firm as a substitute for a set of contingent claims markets (Loasby 1976, p. 65) and as an arena for equilibrating processes; but if we also take account of Young's vision of economic progress, we can also regard each firm as part of the mechanism which propels economic systems away from previouslyexisting equilibria. They are local centres of specialisation in coping with particular kinds of uncertainty. This is Knight's (1921, p. 255) 
explanation of the firm as an entrepreneurial creation, which Casson (1982, p. 373) has acknowledged as the basis of much of his theory of entrepreneurship. 'Men differ in their capacity to form correct judgements as to the future course of events in the environment. This capacity, furthermore, is far from homogeneous, some persons excelling in foresight in one kind of problem situations, others in other kinds, in almost endless variety' (Knight 1921, p. 241). Casson (1982, p. 23) defines an entrepreneur as 'someone who specializes in taking judgmental decisions about the coordination of scarce resources', and begins his analysis with the absorption of uncertainty; but, recognising the contributions of Schumpeter and Penrose, he then develops the role of the entrepreneur as innovator.

'With uncertainty present ... the primary problem or function is deciding what to do and how to do it' (Knight 1921, p. 268), and if powers of deduction are assumed to be infallible but limited, the quality of decisions depends on the quality of the premises. Knight notes that this quality improves with experience of particular kinds of situations, and that this improvement takes time (Knight 1921, p. 243), thus providing a basic reason why both the external and internal boundaries of a firm, which provide some boundaries for cognition, should be fairly stable and why performance within those boundaries may get better. The possibility of such improvement was crucial to Smith's and Marshall's theories of economic development. The recognition of uncertainty leads to the analysis of an economy in time, in which future knowledge cannot be predicted but the directions in which knowledge may be increased can be influenced by organisation. Casson's emphasis on the importance of each entrepreneur's distinctive way of organising information as a basis for distinctive rational decisions, which has been a continuing feature of his work (Casson 1997, 2000), is also an emphasis on the importance of the scope of each business and the accumulation of experience, and therefore implicitly on the premises for decision making.

Search is organised on the basis of locally-corroborated conjectures, and the costs of decision making are reduced by postponing decisions and then simplifying the postponed decisions by a commitment to particular relationships and to particular decision premises. Though Coase (1988 [1937]) explains that the creation of a firm leads to the avoidance of subsequent market transactions, he does not go beyond the foundational contract by which a firm is constituted to discuss the costs of creating a decision-making system, and does not refer to Marshall's (1920, p. 377) emphasis on the capital which any successful business must invest in building up its internal and external organisation. He 
therefore never quite states that the costs of a series of decisions may be reduced by appropriate investment, as Casson (1982) does in explaining why firms make markets by guiding the creation of institutional arrangements which simplify particular categories of transactions (Menard 1995, p. 170). Both Coase and Casson, however, are in effect writing about the organisation of knowledge, which provides credible premises for later decisions and plausible procedures for managing the process of decision-making.

In his second article on the firm, Coase (1988 [1972], p. 63) recognised that 'the costs of organizing an activity within any given firm depend on what other activities the firm is engaged in'; that is presumably why 'General Motors [is] not a dominant factor in the coal industry or why A \& P [does] not manufacture airplanes' (Coase 1988 [1972], p. 65). It should be noted that Coase's interest in the scope of a firm is not focussed on vertical integration, as is the case with transaction cost theories. However he does not say why the costs of organising activities should not be additive. The explanation lies in the possibility of reusing knowledge (Langlois 1999) - in the present context the possibility of applying the same set of decision premises over a wider range or a longer series of decisions (Loasby 1976, pp. 72-3). A firm provides an agreed framework of decision premises which both facilitates decision making and generates a pool of experience which may be used to simplify these premises and make them more precise (Williamson 1967, p. 136), thus making additional managerial services available, as Penrose $(1959,1995)$ has explained.

Penrose has shown how the emergence of such additional managerial services may lead to the extension of the scope of a firm's activities, which in the present context may be expressed as the extension of well-established decision premises to a new line of business, thus relying on continuity to carry change. Contrary to a common assumption in economic theory, it is never possible to reuse knowledge without cost; but the costs of reuse within a wellfunctioning organisation into which that knowledge has been integrated can often be much lower than the costs of reuse outside, because the latter may require not only the creation of novel premises and procedures but even the discarding of some that are deeply embedded in established systems. Thus, as Langlois (1992) has pointed out, extensions of scope may be motivated less by the desire to protect rents than by the costs of transferring knowledge to other organisations. A firm may also have advantages as an instrument of local co-ordination because it can internalise important externalities through the specification of the agenda and the criteria for decisions (Loasby 1976, pp. 76-8). 
The organisation of resources within an administrative framework (Penrose 1959, 1995, p. 149) is in part the organisation of compatible decision premises for the effective use and further development of the knowledge which is distributed within the firm. Not all firms succeed in establishing such compatability; and if they do they may subsequently face the insidious problems of neglecting the need for adjustments as their environment changes and even of suppressing enterprise within the firm. At the industry level, however, the danger of suppressing variety in the process of maintaining internal coherence may be mitigated by the variation between firms in the minor premises which they use to interpret their experience; the activities of their rivals may then serve as vicarious experiments. The importance of interfirm variety used to be well recognised within the chemical industry, in which access to knowledge created by rivals through cross-licensing and the role of research departments as importers of technology were major premises of strategy; but it is often overlooked in the pursuit of global scale.

The suppression of necessary variety may be particularly serious if a firm seeks to internalise a cluster of activities which though complementary are sharply dissimilar (Richardson 1972). The difficulties of matching disparate ways of thinking while maintaining compatability between each way and its own particular field of application may be very great; and any concentration of the power to decide as a protection against the opportunism that specificity of distributed knowledge appears to make possible is liable to impede both the present use of that specific knowledge and its further development. Interfirm collaboration, of varying degrees of formality, is often a sensible response to the dilemma of organisational versus activity-focussed compatability, because this minimises the interface between very different ways of structuring problems and facilitates the development of very specialised skills to cope with these difficulties, with the aim not of reducing the costs of this class of transactions but of maximising their net value (Kay 1997).

All organisational design is conjectural (Egidi 1992, pp. 166-8). In order to make problems manageable it relies on a combination of opposing principles of decomposition and aggregation: issues which are believed to be sufficiently similar are bundled together (remember Knight's necessary but dangerous principle for living intelligently), and separated from other issues by the definition of each manager's responsibility, which is at once a grant of independence and a prohibition of trespass. Problems and perceptions are framed in a way that, it is hoped, will keep down the costs of decision without 
significantly damaging their quality. The organisational definition of decision spaces creates the local environments within which the trial and error learning takes place that drives economic progress according to Smith's basic principle. But this learning is itself subject to error: the inescapable difficulties of identifying causality in any complex system (the Duhem-Quine problem) are aggravated by the falsehoods that are necessarily incorporated in any organisational design and reinforced by the natural human tendency to take credit for success and assign the blame for failure elsewhere (Levinthal 2000). This propensity to error strengthens the argument for variety across firms, and also supplies a cognitive underpinning to Young's (1928) association of increasing returns with a changing organisation of industry.

\section{Authority, Trust and Strategy}

As Marshall emphasised, the importance of firms in economic development lies in their organisation of knowledge. (That this organisation might become seriously defective was a problem that can readily be discerned in Marshall's (1919) Industry and Trade). In the process they are sometimes - though certainly not always - more effective than market relationships in 'transforming a conflict system into a co-operative system' (Levitt and March 1995, p. 12); but this is not to be explained solely, or even mainly, by their power to curb opportunism. Indeed, what is striking to anyone who observes human behaviour is how many occasions for opportunism are not taken. Adam Smith (1976 [1759]), we should not forget, had a theory of moral sentiments which is still applicable to small and relatively stable communities, and these may include groups within organisations; but self-interest may often be sufficient to explain why we so often accept other people's premises for our actions. It is so much simpler than constructing our own; indeed, as has already been pointed out, we do not have the capacity to supply more than a small proportion of our own premises for making sense of the situations that we encounter or for deciding what to do about them.

The more complex our economy and our society become the more dependent we are on premises supplied by other people. It is often a relief rather than a cause for complaint to accept the decision premises of an organisation rather than provide our own; many people prefer employment to independence (Knight 1921). When we recognise the cognitive problems of constructing a coherent preference ordering it is not even difficult to understand how we may come to internalise organisational preferences, notably in the form of 
corporate culture, which for good or ill inhibits challenge to the current institutions, and may even make those institutions undiscussable (Argyris 1994). Many economists, it may be observed, seem to be very comfortable with the decision premises in which they have been trained, and some find it hard to perceive what there might be to discuss about them.

Chester Barnard (1938, p. 163) emphasised that it was the recipient of any communication who decided whether it was authoritative; and all of us are very happy to find sources of communication to which we can grant authority, even when we could apparently do better for ourselves by ignoring them (Reynaud 1996). Firms provide an environment in which members may develop good reasons for deciding whose authority they can rely on as premises for their own decisions - or as we might say, who can be trusted - for no organisation can work effectively unless each of its members is prepared to accept the word of many others, most of whom are not their formal superiors. As Kay $(1997$, p. 215) has pointed out, it is very often the case that people agree to work together not because they trust each other but in order to discover whether they can reasonably trust each other, which of course cannot be done without exposing oneself to opportunism. But if knowledge is specialised, trust is indispensable. What is missing in the analysis of organisational equilibria which is based on transaction costs is the effect of process on attitudes and arrangements; and it is missing because the premises of the analysis exclude it.

A firm is an interpretative system, within which people develop common ways of understanding, and common ways of responding to what they believe they have understood. Especially in a new firm, there may be a strong entrepreneurial element in this interpretation; as Martin Fransman (1995) and Ulrich Witt (1998) have emphasised, a firm may be the location for the construction of beliefs by which interpretative ambiguity is resolved. (The resolution may be erroneous, or even disastrous; no guarantees are available.) Ambiguity, of course, is also the arena for opportunism, and it is not unknown for people to construct beliefs in which they have no faith but which they use to deceive others; but the desire to impose order is so insistent that almost any pattern which is not incompatible with our presently serviceable set of connecting principles may seem preferable to fragmented knowledge, and crowd out opportunism. Often it crowds out the entrepreneur's own opportunism; Schumpeter was probably right in his implicit assumption that entrepreneurs believed their own promises.

In models of efficient and inefficient allocation, strategy can hardly be other than an efficient set of paths through a decision tree or a set of actions by which to gain some monopolistic advantage. 
But business strategy, like military strategy, belongs in a world of uncertainty; it is a means of resolving ambiguity into a coherent set of major premises which promotes the compatability of decisions over time and across decision makers. Soon after he had joined the research department of a Division of ICI, my former colleague Frank Bradbury was writing down the formulae for some chemical compounds that he thought might have some commercial application when his manager walked past; after scanning the list he simply asked 'Where's the chlorine, Frank?' At that time the Division produced chlorine in large quantities as a by-product, and its researchers had considerable expertise in chlorine chemistry; it was therefore natural to impose the use of this by-product and these skills as decision premises for research. In a similar fashion, at a time when BP had an unmatched reputation for discovering productive oilfields but not for marketing the products, the Research Director of BP Chemicals told his research staff 'The objective of this Department is to shift crude'.

Strategic decision premises provide structure to a complex set of decisions which might otherwise be incoherent. But no choice is without opportunity costs, and the pathology of the focus which is provided by strategy is bias. Both technological foresight and technological oversight may often be explained by the decision premises on which crucial decisions were based. For example, neither the top management of major corporations nor a technologically-based firm of consultants could see any reason why anyone should buy a photocopier to do what was already accomplished by a typist using carbon paper (Brown 1997, pp. 97-8); the contract by which IBM bought DOS from Microsoft, and which now appears to have been a disastrous blunder by the former and a brilliant coup by the latter, was carefully tailored to the localised decision premises of both parties, neither of whom was blessed with rational expectations (Porac 1997); and the precisely-calculated performance limits of optical lithography rested on well-defined physical, technical and production constraints which proved not to be binding (Henderson 1997). On the other hand, a novel set of decision premises may lead an entrepreneur to deduce the possibility of a major innovation. It is not necessary for any single premise to be new; as Schumpeter (1934) claimed, what matters is the combination, though what he did not emphasise is that this combination may follow a good deal of development in what are to become the components of the new vision. 


\section{Conclusion}

Decision premises are required for decision processes. Theories of equilibrium states, even when based on the concept of rational choice, have no place for decision processes, for in equilibrium there are no decisions to be made. The best theorists have recognised that behaviour out of equilibrium cannot be analysed with the standard and type of rigour that is now expected, and so they choose theoretical premises that exclude it. One of the attractions of game theory is that there are no out-of-equilibrium moves; and one of its limitations is that multiple solutions or inconsistency within the logic of backward induction make out-of-equilibrium thoughts hard to avoid. Transaction cost economics, as a theory of efficient allocations, is essentially an equilibrium theory, and also avoids behaviour out of equilibrium; in an equilibrium theory of organisation the transaction is indeed the appropriate unit of analysis and the decision premise is not.

If economics is to be defined as the study of fully-defined allocation problems, in which it increasingly appears that the key requirement is incentive compatability based on rational expectations (Myerson 1999), then that is the end of the matter except perhaps to tidy up a few internal inconsistencies by deleting such concepts as money and the firm as an organisation. But modern economics began with a theory of economic development, propounded by a man who was deeply concerned with the possibilities of human understanding, human communication, sensible action and the possibilities of self-deception. Within that tradition it seems important to pay attention to the formation and development of the premises on which people reason and the knowledge and skills which they may acquire as a consequence of economic organisation.

Nelson and Winter (1982) suggested that the standard distinction between choice and the use of chosen technology is potentially misleading; both are activities which require appropriate capabilities deployed within suitable frameworks, as Penrose and Richardson have argued. Activities and capabilities are highly problematic, very diverse, and may be combined and developed in many ways; therefore they merit a great deal of attention, in which the causal links with organisation are bi-directional. Activities are linked by interfaces, which are justifiably the special concern of transaction cost economics; but I agree with Coase, and with Demsetz (1997), that problems of knowledge which do not qualify as agency problems provide important theoretical premises for 
explaining the choice of transaction mode. I would go one stage further, and argue that the management of a class of transactions, or of a particular governance relationship, is itself an activity, and the effectiveness of that management depends on the evolved capability of the person, or persons, who are doing the managing. Since management requires decisions, its quality depends upon the managers' decision premises. Therefore the analysis of transaction costs and of decision premises should be incorporated within the analysis of activities and capabilities, which is fundamentally an analysis of processes and institutions.

\section{References}

Argyris, Chris (1994) 'Good communication that blocks learning', Harvard Business Review, Jul-Aug, pp. 77-85.

Barnard, Chester I. (1938) The Functions of the Executive. Cambridge MA: Harvard University Press.

Brown, John S. (1997) 'Changing the game of corporate research: learning to thrive in the fog of reality', in Garud et al. (1997), pp. 95-110.

Casson, Mark (1982) The Entrepreneur: An Economic Theory. Oxford: Martin Robertson.

Casson, Mark (1997) Information and Organization. Oxford: Oxford University Press.

Casson, Mark (2000) Economics of International Business: A New Research Agenda. Cheltenham UK and Northampton MA, USA: Edward Elgar.

Chamberlin, Edward H. (1933) The Theory of Monopolistic Competition. Cambridge MA: Harvard University Press.

Choi, Young B. (1993) Paradigms and Conventions: Uncertainty, Decision Making, and Entrepreneurship. Ann Arbor: University of Michigan Press.

Coase, Ronald H. (1988 [1937]) 'The nature of the firm', in The Firm, The Market and the Law. Chicago: University of Chicago Press, pp. 33-55. First published in Economica, N.S. 4, pp. 386-405.

Coase, Ronald H. (1988 [1972]) Industrial organization: a proposal for research', in The Firm, the Market and the Law. Chicago: University of Chicago Press, pp. 57-74. First published in Victor R. Fuchs (ed.) Policy Issues and Research Opportunities in Industrial Organization. New York: National Bureau of Economic Research, pp. 59-73.

Currie, Lauchlin (1997) 'Implications of an endogenous theory of growth in Allyn Young's macroeconomic concept of increasing 
returns', ed. Roger J. Sandilands, History of Political Economy, 29, pp. 413-43.

Demsetz, Harold (1997) The firm in economic theory: a quiet revolution', American Economic Review, 87, pp. 426-9.

Douglas, Mary (1995) 'Converging on autonomy: anthropology and institutional economics', in Williamson (ed.) (1995), pp. 98-115.

Egidi, Massimo (1992) 'Organisational learning and the division of labour' in Herbert Simon, Massimo Egidi, Robin Marris and Riccardo Viale (eds) Economics, Bounded Rationality and the Cognitive Revolution. Aldershot and Brookfield VT: Edward Elgar, pp. 148-73.

Fransman, Martin (1995) Japan's Computer and Communications Industry. Cambridge: Cambridge University Press.

Garud, Raghu., Nayyar, Praveen R. and Shapira, Zur B. (eds) (1995) Technological Innovation: Oversights and Foresights. Cambridge: Cambridge University Press.

Heiner, Ronald A. (1983) 'The origin of predictable behavior', American Economic Review, 73, pp. 560-95.

Henderson, Rebecca (1997) 'On the dynamics of forecasting in technologically complex environments: the unexpectedly long life of optical lithography', in Garud et al (1997), pp. 147-66.

Hicks, John R. (1939) Value and Capital. Oxford: Oxford University Press.

Kay, Neil M. (1997) Pattern in Corporate Evolution. Oxford: Oxford University Press.

Knight, Frank H. (1921) Risk, Uncertainty and Profit. Boston: Houghton Mifflin. Reprinted Chicago: Chicago University Press, 1971.

Langlois, Richard N. (1992) 'Transaction cost economics in real time', Industrial and Corporate Change, 1, pp. 99-127.

Langlois, Richard N. (1999) 'Scale, scope and the reuse of knowledge', in Sheila C. Dow and Peter E. Earl (eds) Economic Organization and Economic Knowledge. Aldershot: Edward Elgar, pp. 239-54.

Leijonhufvud, Axel (1998) 'Mr Keynes and the moderns', European Journal of the History of Economic Thought, 5, pp. 169-88.

Levinthal, Daniel A. (2000) 'Organizational capabilities in complex worlds' in Giovanni Dosi, Richard R. Nelson and Sidney G. Winter (eds) The Nature and dynamics of Organizational Capabilities. Oxford: Oxford University Press.

Levitt, Barbara and March, James G. (1995) 'Chester Barnard and the intelligence of learning' in Williamson (ed.) 1995), pp. 11-37.

Loasby, Brian J. (1976) Choice, Complexity and Ignorance. Cambridge: Cambridge University Press.

Loasby, Brian J. (1998) 'The organisation of capabilities', Journal of Economic Behavior and Organization, 35, pp. 139-160. 
Loasby, Brian J. (1999) Knowledge, Institutions and Evolution in Economics. London: Routledge.

Loasby, Brian J. (2002) 'Content and method: an epistemic perspective on some historical episodes', European Journal of the History of Economic Thought, 9 (1).

Marcuzzo, Maria Christina (2001) 'Sraffa and Cambridge economics 1928-31, in Cozzi, Terenzio and Marchionatti, Roberto (eds) Piero Sraffa's Political Economy: A Centenary Estimate. London and New York: Routledge.

Marshall, Alfred (1919) Industry and Trade. London: Macmillan.

Marshall, Alfred (1920) Principles of Economics, $8^{\text {th }}$ edn. London: Macmillan.

Ménard, Claude (1995) 'Markets as institutions versus organizations as markets? Disentangling some fundamental concepts', Journal of Economic Behavior and Organization, 28, pp. 161-82.

Myerson, Roger B. (1999) 'Nash equilibrium and the history of economic theory', Journal of Economic Literature, 37, pp. 1067-82.

Nelson, Richard R. and Winter, Sidney G. (1982) An Evolutionary Theory of Economic Change. Cambridge MA: Belknap Press.

Penrose, Edith T. $(1959,1995)$ The Theory of the Growth of the Firm. Oxford: Basil Blackwell. $3^{\text {rd }}$ edn. Oxford: Oxford University Press.

Porac, Joseph F. (1997) 'Local rationality, global blunders, and the boundaries of technological choice' in Garud et al (eds) (1997), pp. 129-46.

Potts, Jason (2000) The New Evolutionary Microeconomics. Cheltenham UK and Northampton MA: Edward Elgar.

Ravix, Jacques-Laurent (1997) 'Fondements critiques pour une analyse de la dynamique industrielle: la méthode de Allyn Young', Revue Économique, 48, pp. 965-88.

Reynaud, Bénédicte (1996) Types of rules, interpretation and collective dynamics: reflections on the introduction of a salary rule in a maintenance workshop', Industrial and Corporate Change, 5, pp. 699-721.

Richardson, George B. (1972) 'The organisation of industry', Economic Journal, 82, pp. 883-96.

Robinson, Romney (1970) Edward H. Chamberlin. New York: Columbia University Press.

Samuelson, Paul A. (1972 [1967]) 'The monopolistic competition revolution', in Robert K. Merton (ed.) The Collected Scientific Papers of Paul A. Samuelson. Cambridge MA and London: MIT Press, pp. 18-51. First published in R. E. Kuenne (ed.) 
Monopolistic Competition Theory: Studies in Impact. New York: Wiley, pp. 105-38.

Schumpeter, Joseph A. (1934) The Theory of Economic Development. Cambridge MA: Harvard University Press.

Shackle, George L. S. (1961) Decision, Order and Time. Cambridge: Cambridge University Press.

Simon, Herbert A. (1976) Administrative Behavior, $3^{\text {rd }}$ edn. New York: Free Press.

Smith, Adam (1976 [1759]) The Theory of Moral Sentiments, ed. David D. Raphael and Alec L. Macfie. Oxford: Oxford University Press.

Smith, Adam (1980 [1795]) 'The principles which lead and direct philosophical enquiries: illustrated by the history of astronomy' in Essays on Philosophical Subjects, ed. William P. D. Wightman. Oxford: Oxford University Press, pp. 33-105.

Sraffa, Piero (1926) 'The laws of return under competitive conditions', Economic Journal, 36, p. 535-50.

Sraffa, Piero (1998 [1925]) 'On the relations between cost and quantity produced', trans. John Eatwell and Alessandro Roncaglia, Italian Economic Papers, 3, pp. 323-63. First published in Annalia di Economia, 2, pp. 277-328.

Sraffa, Piero (1930) 'A criticism - a rejoinder, Economic Journal, 40, pp. 89-93.

Williamson, Oliver E. (1967) 'Hierarchical control and optimum firm size', Journal of Political Economy, 75, pp. 123-38.

Williamson, Oliver E. (1996) The Mechanisms of Governance. New York and Oxford: Oxford University Press.

Williamson, Oliver E. (ed.) (1995) Organization Theory: From Chester Barnard to the Present and Beyond, expanded edition. New York and Oxford: Oxford University Press.

Witt, Ulrich (1998) 'Imagination and leadership - the neglected dimension of an evolutionary theory of the firm', Journal of Economic Behavior and Organization, 35, pp. 161-77.

Young, Allyn A. (1928) 'Increasing returns and economic progress', Economic Journal, 38, pp. 527-42.

Ziman, John M. (1978) Reliable Knowledge. Cambridge: Cambridge University Press.

Ziman, John M. (2000) Real Science. Cambridge: Cambridge University Press. 